\title{
SCIENCE IN GENERAL EDUCATION
}

\author{
- \\ Andrew F. Read

\begin{abstract}
AB STRACT
General education must develop in students an appreciation of the power of science, how it works, why it is an effective knowledge generation tool, and what it can deliver. Knowing what science has discovered is desirable but less important.
\end{abstract}

Surely one aim of that uniquely American learning aspiration we call general education is to give college graduates the capacity and the confidence to think for themselves about big questions. One of the biggest questions is the human condition. Why are we such a bundle of contradictions? How can we be both selfless and selfish? How can the same person be kind to animals and instigate the Holocaust?

In The Social Conquest of Earth, E. O. Wilson, a scientist who has spent his life studying insects, proposes a radical answer: "The human dilemma was foreordained in the way our species evolved. . . . [G] ood and evil was created by multilevel selection, in which individual selection and group selection act together on the same individual but largely in opposition to each other" (2012, p. 24I). This is an audacious hypothesis. Many people, including philosophers, novelists, and religious leaders, offer very different perspectives. Wilson says that none can have the answer because an explanation cannot be generated by introspection alone. Instead, he unapologetically offers an aggressively scientific answer: evolution made us so.

What is a well-educated citizen to make of this argument? She is almost certainly not a science graduate. How is she to decide whether Wilson's argument is worth considering at all? If she does consider it, how is she to evaluate it? More generally, what does a nonscientist need to have a fighting chance of generating an informed understanding of any scientific claim?

For several years now, I have been trying to equip nonscience majors with the skills to evaluate science that impacts their lives or worldview. This science

The Journal of General Education: A Curricular Commons of the Humanities and Sciences, Vol. 62, No. I, 20I3 Copyright (C) 2013 The Pennsylvania State University, University Park, Pa. 
impacts important everyday issues such as Oprah's latest diet advice, politically charged assertions about climate change, and profound ideas like Wilson's or indeed Feynman's notion that we are "lost in a mysterious universe without having any purpose" (198I). What intellectual machinery do nonscientists need to make sense of these claims?

In the case of Wilson's evolutionary argument, the superficial answer is that well-educated citizens need an understanding of biological evolution and the concepts of multilevel, group, and individual selection. And certainly, as a professional evolutionary biologist, I strongly believe that everyone has the right to a working understanding of evolution. It is impossible to make sense of life without it. But colleagues in other disciplines say the same thing about their specialty. It has been put to me, for example, that nothing makes sense in the world if you do not understand the Second Law of Thermodynamics, or a covalent bond, or the difference between transcription and translation.

All that may be true, and there is little doubt that it is easier to appreciate the workings of the natural world if you know a little about those workings. But I think that nonscientists do not need to know much about the things scientists have discovered to be scientifically literate citizens. Moreover, it is hard to prioritize scientific knowledge, particularly when there is no guarantee which bits of today's knowledge will be relevant to tomorrow's challenges. So long as we teach our students how to find things out, it is not that important to know facts. It is certainly unimportant when evaluating the claims of writers like Wilson who explain the necessary scientific knowledge and concepts well enough.

Instead, I think that scientifically literate citizens need to understand how scientists discover things. From a critical appreciation of how science works flows an ability to distinguish good science from weak science, science from pseudoscience, and science from humbug. Full appreciation also generates an understanding of what science is and is not capable of delivering, of how science interfaces with other spheres of intellectual thought, and most important of all, that while science is far from infallible, it is the best knowledge acquisition system humanity has yet devised. If Wilson's science is good, and the citizen needs to be able to make that call, then his argument will be worth paying attention to. If we give our students a successful general education, they will be able to judge his arguments for themselves. We can even empower them to apply the scientific approach-essentially rational thinking-to their everyday lives.

\section{Essential Concepts}

In what follows, I summarize the core concepts I think we need to get across to nonscience students. My ideas on this have been shaped by the writings 
of a number of scholars and commentators (Dean, 2009; Delbanco, 20I2; Lewis, 2006; Mooney \& Kirshenbaum, 2009; Olson, 2009; Otto, 20II) and in particular Carl Sagan, in his outstanding The Demon-Haunted World: Science as a Candle in the Dark (1997). Even more influential has been my experience teaching nonscience majors at Penn State. They take my course because they are forced to do natural science gen ed credits. For the most part these students are intelligent, engaged, and easily stimulated. I continue to be appalled at their $\mathrm{K}-\mathrm{I} 2$ science and math experience. Not only did they learn little about how science actually works, they also acquired little of the awe and inspiration science can generate. For the most part, they gained instead a visceral loathing of math and science that inhibits their ability to generate an informed understanding of the world about them and their place in it.

\section{Science Works}

Why should a well-educated citizen pay attention to a scientific account of the human condition or, indeed, any scientific claim? The first-order answer is that science has been immensely successful. This obvious truism is not obvious to my students, who frequently prefer conspiracy theories, astrology, and homeopathy over the hard-won conclusions of science. Part of the problem is that when science reaches a firm conclusion (smoking is bad for you), it can become hard to imagine that people ever thought otherwise. We need to expose our students to success stories.

However, we have to be careful with the history of science. In my experience, the narratives we use have to be as contemporary as possible. Old ideas (the planets go around Earth) seem quaintly irrelevant to young people. Recent and ongoing failures of modern medicine when practiced without science provide a rich seam of examples (Burch, 20ro). These can be used to show that science is worthy of attention because it can be very successful. For instance, showing students that it took just a decade to overturn the completely erroneous notion that stress causes stomach ulcers provides a very powerful lesson because the students themselves still hold the old medical orthodoxy that ulcers are caused by stress.

\section{Science Is Extraordinarily Effective at Rooting Out Rubbish}

Science works because it is very good at discovering sloppy thinking. It does this by crowd-sourcing criticism. We humans are not very good at finding fault in ourselves, but we are very good at finding fault in others. Science exploits this asymmetry. The cultural norms, institutional arrangements, and reward systems 
of science mean that scientists revel in finding holes in other people's science. Students need to appreciate this; it is unlike most other aspects of life (imagine a religious leader seeking criticism of fundamental tenets).

Thus, scientists put great store on the notion that ideas and logic must be clear. Transparency is essential. Secrecy is abhorrent. Data used to support or refute an argument have to be clearly explained so that studies can be repeated or the strength of the data can be assessed. The obfuscation characteristic of other human enterprises (courtroom battles, political debate) is detested.

The concept of peer review is important here, but we need to get across that this means much more than the formal process of inviting experts to take potshots at grants or academic papers from the protective cloak of anonymity. Informal review also goes on within lab groups and within departments and then at external seminars and conferences. The continual doubting goes on well before publication and well after. The more important the idea, the more attention it gains, and the more witheringly critical other scientists become.

Peer review is far from perfect, but it is the best system yet devised for finding flaws. It is the reason scientists generally accept conclusions in scientific fields beyond their own. I do not have the technical skills to evaluate climate change data, but I accept that many scientists in that field do, and if there is a consensus opinion that the planet is warming because of human activities, I accept that. If the best minds in the business have been trying to shoot that notion down and it is still standing, my experience in science tells me that there must be something in it.

Wilson builds his arguments from a large body of evolutionary science. Each building block in the argument has been subject to rigorous review, and so we can have more confidence in it than in the counterarguments of a religious leader. No one is more critical of an evolutionary hypothesis than other evolutionary scientists.

\section{Science Is Antiauthoritarian}

In science, there is no constitution, no supreme court, no pope, no bible, no manifesto, no dictator, no president, and certainly no divine revelation. At its best, science is evidence-based, not eminence-based. Wilson's authority as a senior Harvard professor is not the reason to treat his arguments more seriously than anyone else's. Instead, it is that he is likely thinking bravely. This is an important lesson for students raised on the notion that there is a textbook with answers in it. Anyone can overturn that knowledge if their arguments (and data) are better than those that have come before. Scientists have been given permission by the system to think for themselves, and when that happens, 
diseases can be cured; the weather, forecast; and our place in the cosmos, revealed. This is an important lesson for students, with a moral that extends way beyond science.

\section{Science Struggles to Deliver Certainty}

"Scientific knowledge is a body of statements of varying degrees of certaintysome most unsure, some nearly sure, none absolutely certain" (Feynman \& Leighton, 1988, p. 146). We need to show our students that scientists use words such as fact, theory, certainty, knowledge, and proof in ways different from nonscientists. Proof even means a very different thing in mathematics.

Wilson's argument is based on his judgment of the best scientific knowledge currently available. Quite probably that is different from someone else's judgment or, indeed, even his own of twenty years ago. It may be different again twenty years hence.

\section{The Scientific Process Is Messy}

Students somehow learn at school that science is a recipe: Crank the handle, and out comes the answer. In reality, there are arguments, conflicting data, changing opinions, unrepeatable results, dead ends, misunderstandings, fads, and fashions. This is because scientists are not clairvoyants. If they knew the answer in advance, they would all go there the first time. But real researchers are groping in the dark. Given enough time, knowledge emerges. To onlookers, the process in action can look very confused, as if nothing worthwhile is going on (butter bad, butter good, butter bad). But solid conclusions can eventually emerge (smoking is bad for you). Controversy is not a sign of weakness. Indeed, as Wilson discusses in his book, he is currently embroiled in very heated debates about the nature of natural selection. This in no way means that his arguments about the human condition can be safely ignored. The scientifically literate citizen should be able to see whether the scientific controversies impact the main thesis (in Wilson's case, they do not).

\section{Not All Data Are Equal}

Much of science is vigorous argument about the strength of inference that can be drawn from particular data. There are general principles here that scientifically literate citizens can with a bit of practice acquire. This gives them a cognitive tool kit for assessing data that impact on decisions in their own lives, as well as assessing the quality of scientific inference. Critical are the differences 
among anecdotes, thought experiments, personal experiences, observational (correlational) data, and experiments that manipulate putative causal variables. So too is an understanding of what is possible. There is little doubt that smoking is bad for you, but that "fact" has never been established by a randomized controlled trial. Equally important are what it means when evidence is absent, when different studies reach conflicting conclusions, and how chance works. For my money, all scientifically literate citizens need a smattering of statistics: what "statistical significance" means, relative versus absolute risk, and the notion of scientific errors (the essential basics are wonderfully summarized by Cope [2006] and Russell [2006]).

\section{Science Can Do the Supernatural}

For reasons not clear to me as a professional scientist, my students have trouble grasping the distinction between a supernatural explanation, which scientists are not allowed, and a scientific explanation of allegedly supernatural phenomena, which has been the great triumph of science: "Microbiology and meteorology now explain what only a few centuries ago was considered sufficient to burn women to death" (Sagan, 1997, p. 26). In the context of the human condition, the distinction between mysterious phenomena and mystical explanation is critical.

\section{Science Generates Wonder and Awe}

We owe it to our students to instill in them what Dean (2009) calls the Passion, the Beauty, and the Joy. There is a view that scientific understanding takes the wonder out of things. The opposite is true. Imagine if Wilson is correct. Not only would that open the possibility of rectifying some of our pathologies, but it could also provide a stunningly beautiful and intellectually satisfying explanation of the human condition.

\section{Science Is Counterintuitive}

Many of my colleagues think that science is formalized common sense. And at one level it is. When a mechanic is trying to fix a broken car, he or she formulates hypotheses (the battery is flat) and attempts to test them (it still will not start off a different battery). But at another, it is not. It took humanity thousands of years to discover the scientific method, and many people have not. It takes a decade or more to train a professional scientist, one of the longest apprenticeships of any profession. 
The mind-set acquired during this prolonged training is an important reason why science is so walled off from political, entertainment, and religious culture (Mooney \& Kirshenbaum, 2009). Science involves cultural norms that many nonscientists do not find particularly attractive. Scientists have very little respect for bad ideas or sloppy thinking. And they are deeply skeptical, the more so the more outstanding the claim. My sense is that laypeople like none of that. Instead, laypeople are looking for affirmation: They like to be with people who agree with them; they like to be told how things work and what the right answer is. The disagreement, skepticism, and uncertainty that fuel science are an anathema to many. Even less comforting, scientists are prepared to completely abandon long-held, deeply cherished beliefs if the data are good enough. In other spheres of life, the capacity to stick with something despite evidence to the contrary is often admired. Understanding that there is tension between scientific and nonscientific worldviews, and something of the reasons for that, is necessary to appreciate Wilson's often inflammatory assertions - and the likely reaction to those assertions from scholars and commentators with different perspectives.

\section{IO. Science Is Civilizing}

Finally, taught well, an important lesson emerges from the workings of science. This lesson is not directly relevant to assessing scientific arguments like Wilson's. But it may be even more important. The values at the heart of science-rational discourse, openness, transparency, rigor, revulsion of fraud, search for truth, teamwork, respect for past work, imagination, challenge of authority and evidence, honesty, openness to all regardless of race, religion, or gender; these are values that make society better (Serageldin, 20II). Science demonstrates the power of those values.

\section{Packaging}

My experience teaching nonscience majors is that they should not be walked through these concepts as I have listed them above (or a text that covers them, like The Demon-Haunted World [Sagan, I997]). Instead, students learn best from problem solving, case studies, and narratives, each motivated by these concepts but chosen to be exciting, entertaining, and most of all largely free of the facts the students were forced to regurgitate in high school. Narrative case studies of the history of how scientific inquiry solved a problem or made a discovery can show why the process worked as well as it did, why it took so long, what happened when it went wrong, and how things were corrected in a more accessible 
way. Now that the vicious controversy has died away, the history of smoking science has much to say about today's climate change debates—and about the notion that human evil is a result of our evolution. The smoking story also demonstrates that scientific knowledge can have much to contribute to ethical debates-but that scientific knowledge alone is insufficient to reach ethical conclusions.

\section{Coda: A Vision of a Truly General General Education}

The discussion above focuses on what is required to make scientifically literate citizens, to give nonscientists permission to use the tool kit of science in everyday decision making, and also to gain maximum rewards from intellectual discovery, by, for example, really being able to process Wilson's argument. Wilson's book would itself make a great class discussion in a "science for nonscience" class like the one I teach: the claim is that evolutionary biology provides an explanation of evil. But a more radical way to proceed would be to do a course on evil and blend the approaches of the humanities, religion, philosophy, and science together. I think that would do more to create scientifically literate citizens than a course on science. It is much easier to identify what science is, and how it is different from other ways of looking at the world, when it is juxtaposed with things that are not science. A truly synthetic approach would also have the prospect of showing students how to enjoy the values and rewards of intellectual discovery offered by most branches of learned inquiry.

NOTE

Numerous colleagues have discussed with me the challenges of teaching nonscientists science, but I am particularly grateful for ongoing discussion with Mary Beth Williams. I thank Normand Freed and Daniel Larson, for giving me the opportunity to try, and the students of SC200, who do not hesitate to tell me how it is going.

\section{References}

Burch, D. (2010). Taking the medicine. A short history of medicine's beautiful idea and our difficulty swallowing it. London: Vintage.

Cope, L. (2006). Understanding and using statistics. In D. Blum, M. Knudson, \& R. Marantz Henig (Eds.), A field guide for science writers (pp. I8-25). Oxford: Oxford University Press.

Dean, C. (2009). Am I making myself clear? A scientist's guide to talking to the public. Cambridge: Harvard University Press. 
Delbanco, A. (2012). College. What it was, is, and should be. Princeton: Princeton University Press.

Feynman, R. (198I). Great minds: Richard Feynman-The uncertainty of knowledge. Retrieved from www.youtube.com/watch? $\mathrm{v}=\mathrm{QkhBcLk} \_8$ fo\&feature $=$ sub.

Feynman, G., \& Leighton, R. (1988). What do you care what other people think? Further adventures of a curious character. New York: W. W. Norton.

Lewis, H. R. (2006). Excellence without a soul. New York: Public Affairs.

Mooney, C., \& Kirshenbaum, S. (2009). Unscientific America. How scientific illiteracy threatens our future. Philadelphia: Basic Books.

Olson, R. (2009). Don't be such a scientist. Talking substance in an age of style. Washington, D.C.: Island Press.

Otto, S. L. (20II). Fool me twice. Fighting the assault on science in America. New York: Rodale.

Russell, C. (2006). Risk reporting. In D. Blum, M. Knudson, \& R. Marantz Henig (Eds.), A field guide for science writers (pp. 25I-56). Oxford: Oxford University Press.

Sagan, C. (1997). The demon-haunted world: Science as a candle in the dark. New York: Random House.

Serageldin, I. (20II). The values of science. Science, 332, II27.

Wilson, E. O. (2012). The social conquest of Earth. New York: W. W. Norton. 